ljtihad: Jurnal Wacana Hukum Islam dan Kemanusiaan

Vol. 20, No. 2 (2020), pp. 253-268, doi : 10.18326/ijtihad.v20i2.253-268

\title{
Discrimination against wife in the perspective of CEDAW and Islam Mubādalah
}

\author{
Habib Shulton A., Habib Ismail \\ Institut Agama Islam Ma'arif NU (LAIMNU) Metro Lampung, Indonesia \\ E-mail: habibshulton1708@gmail.com, habibismail65@gmail.com
}

DOI: 10.18326/ijtihad.v20i2.253-268

This article analyzed wife discrimination in the household viewed from the perspective of the Convention for the Elimination of All Forms of Discrimination Against Women (CEDAW) and Islam Mubädalah. Regulation of wife obligation in the household are stated in the Marriage Law (UUP), Number 1 of 1974, article 34 paragraph (b) saying that "A wife has duty to manage household affairs as well as possible". The fact shows that the regulation is widely understood literally, hence it creates gender bias stigma and a wife discrimination. The study was a library research using a normative approach, which examined the Marriage Law with qualitative analysis and applied gender justice theories. The research showed that the regulation in the article 34 of the Marriage Law is interpreted textually, which has implications for discrimination against wife roles in the household. As the result, this understanding affects on wife discrimination and againsts gender justice in the perspective of CEDAW and Islam Mubädalah. As the novelty, the authors found that the wife discriminations in the household are due to the strong pratiarchical perspective in the article 34 of Marriage Law, and the article tends to be a masculine perspective.

Artikel ini menganalisis tentang diskriminasi istri dalam rumah tangga perspektif the Convention for the Elimination of All Forms of Discrimination Against Women (CEDAW) dan Islam Mubädalah. Ketentuan tentang kewajiban istri dalam rumah tangga tertulis dalam Undang-undang Perkawinan (UUP) Nomor 1 Tahun 1974, pasal 34 ayat (b) yang menjelaskan "Istri wajib mengatur urusan rumah tangga dengan sebaik-baiknya”. Fakta menunjukkan bahwa ketentuan pasal tersebut banyak dipahami secara literal tekstual, sehingga hal ini menciptakan stigma bias gender dan melahirkan diskriminasi terhadap istri. hasil dari pemahaman ketika dibaca dalam konteks rumah tangga melahirkan stigma bias gender dan istri mengalami diskriminasi. Jenis artikel ini adalah librabry research (penelitian kepustakaan), pendekatan yang digunakan adalah pendekatan normativ, yakni mengkaji UUP dianalisis secara kualitatif dengan teori-teori keadilan gender. Hasil analisis menjelaskan bahwa 
ketentuan Pasal 34 UUP, banyak dimaknai secara tekstual, yang berimplikasi terhadap diskriminasi peran istri dalam rumah tangga. Implikasi yang melahirkan diskriminasi terhadap istri bertentangan dengan keadilan gender (CEDAW) dan Islam Mubädalah. Novelty dari artikel ini penulis penemukan bahwa, diskriminasi terhadap istri dalam rumah tangga disebabkan karena kuatnya patriarkhisme dalam Pasal 34 UUP, dan Pasal tersebut cenderung maskulin.

Keywords: discrimination; article 34 of marriage law; CEDAW; Islam mubädalah.

\section{Introduction}

Indonesia is one of the countries that has ratified the Convention for the Elimination of All Forms of Discrimination Against Women (CEDAW) (Davis, 2019). After the raftification, the state is obliged to implement the principles contained in the women's convention. The implementation of these principles can be in the form of laws and strategic programs to protect women in the form of discrimination and injustice, both in the public and domestic sphere. In addition, the government is also obliged to change cultural practices that are based on patriarchal superiority which has an impact on women's injustice (Asnawi, 2016). However, until this time, women in the domestic/family sphere still experience gender injustice. Especially with regard to the rights and position of husband and wife in the family. This is due to the factor of the legal regulations of the Marriage Law (UUP) Number 1 of 1974, Article 34 paragraph (b), which are widely understood textually, not interpreted as a substance in the contents of the article, so that this gives rise to unfair practices, subordination to the wife in the household, which impacts the wife's right to justice cannot be fulfilled. In fact, when talking about the conception of human rights (HAM), it should not look at gender (husband and wife), wives as women also have human rights that must be fulfilled.

Fulfillment of human rights is the obligation of all countries; human rights values are contained in international documents on human rights as legal regulations to protect and fulfill human values (Shuaib, 2019). The main human rights regulations are contained in the Universal Declaration of Human Rights (UDHR). In Indonesia, human rights regulations are contained in the 1945 Constitution and laws No. 39 on Human Rights. These human rights regulations are an effort to eradicate practices, especially culture, which are full of injustices occurring to society. It cannot be denied that gender injustice accepted by women originates from negative stigmas against women. The negative stigma labeled on women by 
labelling women as weak creatures. Women's labeling as weak are myths that are generated by the perception of society that has been around for a long time. Other myths, for example about sperm as the source of life, the labeling of sperm originates and is owned by men, not women, while women only accept it, this has an impact on the stigma that women are second class and weak human beings (Subhan, 1999). The justification resulted to the social perceptions in the form of a myth that men have a higher value than women. Thus, the discrimination that often occurs in the domestic sphere is a type of discrimination which is a type of gender injustice which ultimately creates gender roles in which one party becomes the superiority of the other.

This perception forms a marginalization on the part of women causing the disability of women's rights to freedom as human beings. What happens in society is that women are inferior to men, resulting to the doctrine of injustice and equality between men and women which gave rise to the patiarchal culture. Patriarchal culture has been in effect for centuries, this is no longer considered an inequality, even this culture has been considered a scientific fact (Dzuhayatin, 1999). The facts in society show the subordinary of patriarchy resulting on the obligation in which the man and the man's thought become the norm base. The erection of space for women's activities and movements is often ratified by the textual meaning of the people towards religious doctrines and laws in which the text is still gender bias. The provisions containing gender-biased reading are reinforced by the existence of gender-biased practices on a domestic basis (Asnawi, 2011). From the background of the above problems, the problem formulations in this scientific paper are: How is wife discrimination in the household from CEDAW and Islam Mubädalab perspectives?

\section{Method}

This was a library research. The authors analyzed The Marriage Law, especially Article 34, and analyzed the extent of these provision implications on discrimination against wife in the household. The approach used was a normative approach. The authors analyzed the laws or norms that guide society, in this case was Article 34 of the Marriage Law, the formulation of the problem was analyzed qualitatively with gender justice theories. 
From the literature review, there are several research articles and books that examine women's rights and gender in the family, including: A book written by Anwar Al-Jundi, entitled "al-Mar'atu al-Muslimah...", (al-Jundi, t.t.: 22-23). In this book, Anwar explained that there is absolutely no justification for equality between men and women. Because in Islam, a man's role has been assigned, so has the woman in Islam. There is a separation between the roles of men and women in Islam. For example, men are prohibited from wearing gold or silk clothes, while women are prohibited from gathering in public places because the woman's body will be seen by the public and this will cause slander. However, Anwar still affirms equality in the context of humanity (human rights), that men and women have the same degree, especially in front of the law. However, Anwar opposes and does not justify gender equality that originates in Western countries, for example related to the inheritance and divorce rights. In Islam, these provisions have been clearly regulated, so that Anwar does not justify equality where equality is contrary to the rules in Islam. The second book was written by Atiyah Soker, in Mausu'ah Usroh (Insklopedi), with the title "Al-Usrotu Tabtariatil Islam, Hukukuzaujizah" (Soker, t.t.) This Book described the rights of wife over husband, and the rights of husband over wife. In chapter II, it was explained that wife must obey her husband, wife must maintain the dignity of her husband, protect the feelings of her husband, and is obliged to take care of the house and educate their children. Furthermore, Dwi Edi Wibowo's research (Wibowo, t.t.) entitled "Peran Ganda Perempuan dan Kesetaraan Gender", this research explained that, between men and women are the same creatures. Between men and women are partners not of the opposite sex. The two of them are created not to oppress but a partner who needs each other. Subsequent research by Saiful Anwar (Anwar, 2015) entitled "Problem Aplikasi Paham Gender dalam Keluarga", this research explained that the concept of gender equality is just hope, delusion and tyranny that must be programmed and applied as an application of gender equality in the family. In addition, gender equality is an agenda that endangers family institutions. Furthermore, Anita Rahmawaty's research (2016), with the title "Harmoni dalam Keluarga Perempuan Karir: Upaya Mewnjudkan Kesetaraan dan Keadilan Gender dalam Keluarga", this research concluded that the relationship between men and women in the family can create a gender partnership as a partnership. 
The difference between the current research and previous research was the explanation of the equality importance in roles and functions in the domestic and public sphere, even in social society. Through partnerships and gender equality in the family, it will create a happy family. From the literature, novelty and GAP analysis of this article lies in the focus of the problem, it is discrimination of wife in the household, the perspectives used were CEDAW and Islam Mubädalah, and the analysis of this article focused on Article 34 of the Marriagae Law clause (b).

\section{Results and discussion}

\section{The principles of CEDAW and mubādalah as the lens of women's justice}

CEDAW is an international convention that was formulated specifically to regulate the protection of women (Samargandi, 2019). The purpose of this convention was to endeavor to eliminate all kinds of discrimination against women. With this convention, countries that agree to the ratification of the convention are fully obliged to apply it in the form of policies and programs to protect and fulfill women's human rights. The Indonesian state has ratified the convention through law No. 7 of 1984 (Asnawi, 2017). The essence of CEDAW is to protect women's rights and justice, and eliminate gender discrimination and inequality in society and in the family.

The CEDAW Convention contains three important principles that must be implemented. The first principle is equality. This means that men and women have the right to have the same equality and degree, both equality before the law and in the joints of life. There is no difference between the two in terms of non-natural roles, all of them have the same opportunity without any limitation of space for movement just because of gender differences. The second principle is non-discrimination. This means that all forms of discrimination are human rights violations, both men and women have basic freedoms as human rights that must be protected. The third principle is the obligation of the state. This means that countries that have agreed to ratify the CEDAW convention are obliged to ensure the creation of equality and the right to justice between men and women and eliminate all kinds of human rights violations. 
With the presence of the state, all citizens can enjoy their rights in the context of economic, social, cultural, civil and political rights. The three principles above contain the prism of women's rights which is a reference for evaluating all kinds of gender discrimination and injustice in society, especially in the realm of the family. The realization of the right to gender equality can only be realized through understanding the three principles above. It can be concluded that, CEDAW is a framework of reference for the legal umbrella for the realization of women's justice formulated by the international community. However, talking about equality and justice between men and women long before the international world formulated the conception of CEDAW as a legal umbrella to protect and uphold women's justice, Islam has arranged in advance which is clearly written in the Koran. In the Koran, the concept referred to as "mubadalab" has been explained. Mubädalab means "to replace, change and exchange". The concept and word mubadalah have been mentioned 44 times with different forms and meanings. In the language, Mubädalab means annoyance (mufa'alah), and cooperation between two parties (musyarakah), or in other words replacing, changing, or exchanging one another. Mubädalab when it is translated into Indonesian means "reciprocity". From the various meanings above, mubädalah is then used as a perspective in the relationship between two parties which contains the spirit and principles of reciprocity. (Kodir, 2019).

One of the legal bases for mubädalah is found in Q.S. Al-Hujurat [49]: 13, in this verse it is explained that Allah has created different humans, both in different forms of gender, ethnicity, nation. The goal is simply to get to know each other. In this verse Allah clearly states that the most noble man with Allah is the most pious man. This means that the degree of human dignity does not lie in the shape of his sex, the color of his skin, his tribe, his wealth, his position or the height of the rank he bears, but what is considered is the most pious human being.

The framework of mubadalah, has three basic meanings. First, that Islam is present for both men and women, so all of its texts must also target both. Second, the principle of the relationship between the two is cooperation, not hegemony and power, or even authoritarian. Third, Islamic legal texts are open to reinterpretation in order to allow the two previous premises to be reflected in any interpretation work. Islamic texts are open to 
meaningful interpretations as an effort to find the idea of morality that lies behind this literal text. Interpretation of texts to find contextualization of the understanding of the Koran. Interpreting the text is not changing or rejecting the text of the Koran, interpretation is only an effort to develop the interpretation of the Koran. The possibility of interpretation based on mashlabah (human good) considerations. The flexibility of Islamic law in practice and enforcement of ijtihad activities (independent legal reasoning) is sufficient to indicate that Islamic law is adaptable to social changes and the dynamics of space and time, so that it is very possible for reform efforts (Asnawi, 2012a). From the three previous premises, the basic understanding is that men and women are the subject of the revelation of the verse of the Koran. So, both men and women must accept the consequences of the law that is raised. Surely, the law is not lame or biased. The relationship that is built must be cooperative, no one is superior to the others. In the end, the meaning of religious texts must be in line with the great goal of Islam, it is as a religion of mercy for all nature, not only for one type of human being or a certain group.

\section{Discrimination against wife in household CEDAW perspective}

Legal regulations governing the rights and obligations of husband and wife are written in Article 34 of the Marriage Law. However, in this article the authors focused on paragraph (b) which states that "the wife is obliged to manage household affairs as well as possible". This provision is as if all household matters in all their forms are the wife's mandatory duty. These duties have been formalized and legalized in the form of laws, so that women are legally confirmed as officers in the domestic sphere. This regulation has created a stigma that household affairs are a task and a role that must be done by women. In addition, this stigma unwittingly gives birth to a segregation of space to restrict women's movements.

The word "obliged to manage household affairs" is sexually unfair and is gender biased. Household matters such as kitchen matters, washing clothes, sweeping, mopping the floors and so on, seem to have been standardized and obligatory to be carried out by wife (Gupta, 2019). Even though these jobs are roles. Since it is called roles, it can be done by anyone, not only wives but husbands can also do all the work. The formulation of the article gives the impression that the heavy household work is natural. So that it must be done by wife, 
because it is natural for wife, men cannot and no one wants to do these household chores, this is clearly contrary to justice and gender equality.

Gender equality of husband and wife is between husband and wife having the same equality in all fields, without any restrictions and discrimination. But equality for the sake of justice is in the non-natural zone. Non-natural categories in the public sphere include the role of being a leader (Regent, Mayor to President), in the domestic sphere such as playing a role in cooking and taking care of other household matters. This non-natural role, can be done by anyone, it can be a husband or a wife. As an illustration, for example, the husband is on duty or takes the role of cooking and takes care of household matters, while the wife acts as a career woman, or vice versa. The concept is the application of gender equality between husband and wife. This equality makes husband and wife in the household as partnerships.

Referring to the opinion of Khoirudin Nasution, the definition of husband and wife patnership in the household means that a married couple must help each other in all household matters. Domestic affairs should not be fully borne by the wife, but the husband can also play an active role in taking care of household affairs, both of them have the ability to play the same role that is carried out by this role by continuing to promote communication and mutual deliberation in a democratic manner. If the roles in household chores are carried out together as partners, the family will create a democratic, comfortable family, and avoid both physical and psychological violence (Nasution, 2005).

The implementation of partnership principle between husband and wife in the domestic space needs to be understood that between the two of them no one feels higher or lower. Husband and wife are obliged to obtain the same rights and obligations in carrying out all household affairs. In doing household chores, the husband's work is as important as the work of a wife. This means that domestic work can also be done by husbands, while the wife earns a living or have a career. The form of marriage that applies the principle of partnership between husband and wife has the same opportunity to both play a role in any field of work. Funds that are no less important are decisions and deliberations between the two of them based on their needs, agreements and satisfaction (Zahara, 2017). 
Applying the relationship between husband and wife in the family work space must be done first with collective deliberation system. This partnership will be an obstacle if the decision is only taken by one party. The ending of this partner between husband and wife is a participatory democracy. This means that husband and wife participate, are decided, finalized and an agreement is formulated together. Democracy in husband and wife relations is required to open up space to receive opinions and suggestions from partners. Between husband and wife are required to create an attitude of mutual respect for each other, by respecting each other a conducive family will be created, automatically between partners will result to friendship, partnership and the same equality without discrimination (Nasution, 2005).

Gender equality in households by upholding partnership values has not been understood as something that must be applied in households. So that many wives in the household have a dual role of working, including working as career women, and working to take care of household affairs. This is due to the understanding of the community about taking care of household affairs, the law must be carried out by the wife, because indeed the provisions and rules regarding managing household affairs are stipulated in Article 34 of the Marriage Law. When the article is interpreted textually, it will create a stigma that household affairs are things that must be done by the wife. As a result, the wife feels that she has received injustice and her rights and obligations are less balanced and equal. The provisions of Article 34 paragraph (b) above, are not in accordance with and contrary to the principles mandated by CEDAW, as contained in CEDAW Article 1 which explicitly concerns the importance of equality and non-discrimination. This provision explains the importance of creating equality between men and women in any aspect, especially in the family. The provisions of the Article above are also not in line with the principle of nondiscrimination. Due to the provisions of the Article above, by many people it only takes it literally as it sounds the article. So that in society there are many facts of discrimination against wives, because they are forced to keep doing all household matters, this is a form of discrimination against women.

In essence, the provisions of CEDAW emphasize equality and justice, all forms of discrimination against women must be eliminated (Ss., 2015). CEDAW prohibits the 
practice of gender-based superiority of one sex. Because in principle, men and women have equality and equality in all fields including an active role in domestic work. The principle of equality is also emphasized in the 1945 Constitution which emphasizes equality before the law, which is written in Article 28B paragraph (1) and (2) as well as Article 28D paragraph (1): "Everyone has the right to recognition, guarantee, protection and legal certainty. fair and equal treatment before the law".

The initiator of equality before the law theory is A.V. Diecy, who explained that the rule of law wants the government to have its power under the control of the rule of law, which in a state of law is obliged to fulfill three main elements, among them are equality before the law, meaning equality in legal standing for all citizens, both as individuals and in their qualifications as state officials (Diecy, 2007). Quoting Ramly's opinion about the meaning of equality before the law, is that all citizens must be treated fairly, there is no discrimination, this is the obligation of the government and law enforcers.(Hutabarat, 1985) The degree of equality means that men and women receive the same services and protection before the law. With this balanced position, when dealing with the law, there is nothing special above the law, in legal terms it is usually referred to as "no man above the law", then this is nothing that is leased by law to legal subjects (Risdianto, 2017).

The principle of equality before the law does not see ethnicity, culture, religious beliefs, beliefs, skin color, language and gender, all have the same equality before the law (Asnawi, 2016a). This principle requires that men and women have the same degree in before the law. In a rule of law there is no specialization based on gender, rich or poor, all have a degree of equality in law. This means that if you refer to the provisions of the Marriage Law which stipulate that the wife is obliged to take care of household affairs as well as possible, it is clear that this provision indicates that it is contrary to the principle of equality before the law. With these provisions, all forms of household affairs have been formalized into the duties and roles of the wife, while the husband is not, this is clearly discrediting the wife, because besides doing household chores, the wife also has a job in the public sphere (career women to seek a living), this makes the wife perform multiple roles.

The formulation of Article 34 of the Marriage Law also contradicts the Law No. 39 of 1999 concerning Human Rights in the ninth part of the Human Rights Law on the 
Rights of Women Article 1 paragraph (1) explains that: (Paragraph 1) "A wife while in a marriage bond has the same rights and responsibilities as her husband for all matters relating to her married life, the relationship with his children, and the right to own and manage joint assets". From the analysis above, it is clear that Article 34 of the Marriage Law, which explains that wives are obliged to take care of household affairs as well as possible, contradicts CEDAW and even contradicts various regulations on human rights in Indonesia.

\section{Islam mubādalah perspective}

Long before Western countries voiced equality between men and women, Islam was born with a mission, one of which was to eliminate and free all forms of discrimination against women. Islam explicitly regulates that husband and wife have the same rights and obligations, the degree of human dignity does not lie in gender or wealth, but in devotion. Islam greatly honors women. Among the verses explaining the glory and justice for women contained in Q.S. Al-Hujurat: [13], Q.S. An-Nisa' verse [1] and Q.S. At-Taubah Verse [71]. From the provisions of the Koran, the point is that Islam positions man and woman before God as the same servant (Asnawi, 2012b). In another sense, Islam requires that husband and wife have the same justice and equality. Positioning equality between husband and wife, in Islam it can be referred to as "mubadalab". The meaning of mubadalah means mufa'alah, and cooperation between two parties (musyarakah), or in other words, replacing, changing, or exchanging one another (Adam, 2019).

The rights and obligations of the husband in the household, between the husband and wife, should apply mubadalah or have "each other" point. In the sense that husband and wife are both cooperative in managing household affairs, if all household matters are obliged to become the duty of a wife this is contrary to the annoyance theory. In society, it is often found that wives are charged with taking care of household matters, while husbands are reluctant to help their wives with their duties, this is because of the understanding of the verse of the Koran, Surat an-Anisa: 4 [34] which is always translated: men are leaders for women, in which this verse is understood only textually. It is necessary to understand deeply the translation of "leader" in the verse. The word qown am can be translated into two categories, including qowwam as a leader and qowam not as a leader. 
ljtihad: Jurnal Wacana Hukum Islam dan Kemanusiaan, Volume 20, No. 2, Desember 2020: 253-268

\section{The consequence of "qowwam" translated as leader}

When the word qowwam is translated that men is the leader of the wife in the household, then the leader requested by Islam is a democratic leader who opens opportunities for suggestions and aspirations from a partner, not an authoritarian and arbitrary leader towards spouses or other family members. Husbands who deserve the title of qowwam are husbands who are democratic, full of love and understanding. This means that the husband deserves the title, if the husband has better qualities in terms of intellectual, emotional and spiritual qualities than the wife, then the husband deserves to be called qowwam for a wife. Quoting the opinion of Siti Musdah Mulia (2008) the position of qawwam for the husband is not automatic, but depends on the two conditions that are explained at the end of the verse. It is said that it is not automatic because it can be said that a leader must have two conditions, first the husband must have a higher quality than his wife, and that quality can mean physical, moral, intellectual and financial qualities. The second condition that husbands must have fulfilled their obligation to provide for the family. From these two conditions, it means that the position of the husband as the leader of the wife is not immediately automatic, but is definitive or a certain husband. Based on Arabic knowledge, the word al-rijal in the verse does not indicate all men, but only certain men, what's more that the verse uses the prefix "al" which shows the definitive meaning. If the letter an-Nisa', [34] is read only textually, it will result to the understanding that every man is a leader over women. Thus, the verse should be more accurately interpreted: "only husbands who have certain qualifications can become leaders of certain wives", or "only certain husbands can be leaders for their wives". It must also be accompanied by two conditions as above.

\section{The consequence of qowwam translated not as leader}

Quoting the opinion of Faqihuddin Abdul Qodir (2019) in his book entitled "Qira'ah Mubädalab", that QS. An-Nisa: [34] it is not emphasizing the leadership or responsibility of men towards women, on the basis of gender. This verse is talking about the demands of those who have virtue ( $f a d)$ and property (nafaqah) to be responsible for supporting those who are unable and have no property. That way, the meaning of qawwam in the husband and wife relationship is a fair division of roles in the family between husband and wife which 
is based on mutual respect, wants to protect and be happy for each other (mu'asyarah bi al ma'rüf /QS an-Nisa: 19). In simple terms, qowwam is not who has power over whom, but who can help whom.

In the Islam Mubadalah perspective, the provisions of Article 34 of the Marriage Law which have implications for discrimination on the role of wives in the household, and are contrary to the noble values of Islam, namely equality and gender justice. Islam was revealed on earth to call for humanitarian justice between men and women, the two of them having the same degree of honor. Islam rejects all forms of inequality and injustice, especially in gender relations. The presence of Islam is to erase the practice of Patriarchal culture or jahiliyah culture and all tyrannical systems. Islam eliminates any oppressive paradigm or system that violates human values. Islam upholds universal values of gender equality and human rights.

\section{Conclusion}

The provisions of Article 34 of the Marriage Law paragraph (b), place the wife in a household no longer as equality before the law. The sentence "the wife is obliged to take care of household affairs", as if household duties have been confirmed to be the obligatory duties of a wife. This provision is considered inconsistent with the principles contained in the international convention on women (CEDAW), which regulates the importance of gender equality and justice in the household. In addition, the provisions of Article 34 of the Marriage Law are contradictory to the values contained in mubädalah. In mubädalah, the requirement is that each husband and wife cooperate with each other, respect each other, help each other in household, being happy with each other (happy is making other person happy), husband and wife are a partners. Then, it must be understood that, in reading the word "qawwām" is not enough to read it only textually. The meaning of qawwam in the husband and wife relationship is a fair division of roles in the household between husband and wife which is based on mutual respect, want to protect and be happy for each other (mu'asyarah bi al-ma'rüf /QS an-Nisa: 19). In simple terms, qawwam is not who has power over others, but who can help others. It is clear that Article 34 of the Marriage Law contains patriarchy, which positions the husband to be more noble than the wife, and these 
ljtihad: Jurnal Wacana Hukum Islam dan Kemanusiaan, Volume 20, No. 2, Desember 2020: 253-268

provisions tend to be masculine which is not taking sides with a wife.

From the results of this scientific article, the authors recommend that the provisions of Article 34 of the Law. No. 1 of 1974 concerning Marriage must be revised immediately, because it is full of patriarchal content, which has an impact on gender inequality in the household.

\section{Bibliography}

Adam, A. T. Pembacaan Mubādalah Terhadap Penafsiran Hamka Tentang Poligami. Citra Ilmu, Edisi Vol. 29, No 29 (2019): p. 39-50.

al-Jundi, Anwar. Kitab "al-Mar'atu al-Muslimah fi Wajhi Tahadiad”,. Dārul I'tishām, (t.t.).

Anwar, S. Problem Aplikasi Paham Gender dalam Keluarga. Kalimah, Vol. 13, No. 1 (2015): p. $21-44$.

Asnawi, H. S. HAM dalam Ruang Domestik: Studi terhadap UU. No. 23 Tahun 2004 Tentang PKDRT. al-Mawarid: Jurnal Hukum Islam Vol. 11, No. 2 (2011): p.195-210.

Asnawi, H. S. "Pernikahan Melalui Telepon dan Reformasi Hukum Islam di Indonesa". al-Mazabib: Jurnal Pemikiran Hukum Vol. 1, No. 1 (2012): p. 1-15.

Asnawi, H. S. "Membongkar Patriarkhisme Islam Sebagai Kearifan Budaya Lokal: Sebuah Kritik Terhadap UU. No. 1 Tahun 1974 Tentang Perkawinan.” Esensia: Jurnal Ilmu-Ilmu Ushuluddin Vol. 13, No. 2 (2012): p.

Asnawi, H. S. “Dasar Hukum Hakim Mahkamah Konstitusi dalam Memutuskan Perkara No.46/PUU-VIII/2010 Tentang Status Hukum Anak di Luar Nikah (Perspektif Hukum Islam dan Hak Asasi Manusia)." Fikri : Jurnal Kajian Agama, Sosial dan Budaya, Vol. 1, No. 1 (2016): p. 45-78.

Asnawi, H. S. “Tinjauan Kritis Terhadap Hak-Hak Perempuan dalam UU. No. 1 Tahun 1974 Tentang Perkawinan: Upaya Menegakkan Keadilan dan Perlindungan HAM Perspektif Filsafat Hukum Islam." Mabkamah: Jurnal Ilmu Hukum Dan Hukum Islam, Vol. 1, No. 1 (2016): p. 30-45.

Asnawi, H. S. “Politik Hukum Perlindungan HAM Di Indonesia (Studi Hak-Hak Perempuan Di Bidang Kesehatan).” Jurnal Mabkamah : Kajian Ilmu Hukum Dan Hukum Islam, Vol. 2 No. 1 (2017): p. 77-102. 
Discrimination against Wife in the perspective of CEDAW and Islam Mubādalah (Habib Shulton A, et.al.)

A.V. Diecy. Pengantar Studi Hukum Konstitusi, terjemahan Introduction to the Study of The Law of the Constitution, penerjemah Nurbadi, M.A. Yogyakarta: Nusamedia, 2007.

Dzuhayatin, S. R. "Teologi Feminis Islam Suatu Refleksi Pergulatan Pemikiran Feminis dalam Wacana Islam di Indonesia.” Jurnal Teologi Gema, 55, 1999.

F Davis, M. "Scoping the New Urban Human Rights Agenda." The Journal of Legal Pluralism and Unofficial Law, Vol. 51, No. 2 (2019): p. 260-270.

Faqihuddin Abdul Kodir. Qiräăh Mubädalah. Ygoyakarta: IRCiSoD, 2019.

Gupta, G. R., Oomman, N., Grown, C., Conn, K., Hawkes, S., Shawar, Y. R., Shiffman, J., Buse, K., Mehra, R., Bah, C. A., Heise, L., Greene, M. E., Weber, A. M., Heymann, J., Hay, K., Raj, A., Henry, S., Klugman, J., \& Darmstadt, G. L. . Gender equality and gender norms: Framing the opportunities for health. The Lancet, Vol. 393 (10190) (2019): p. 2550-2562.

Hutabarat, R. Persamaan di Hadapan Hukum (Equality Before The Law), Jakarta: Ghalia Indonesia, 1985.

Mulia, M. Menuju Kemandirian Politik Perempuan: Upaya Mengakbiri Depolitisasi Perempuan di Indonesia. Yogyakarta: Kibar Press, 2008.

Nasution, K. Hukum Perkawinan I. Yogyakarta: ACAdeMIA \& TAZZAFA, 2005.

Rahmawati, A. "Harmoni dalam Keluarga Perempuan Karir: Upaya Mewujudkan Kesetaraan dan Keadilan Gender dalam Keluarga." PALASTREN Jurnal Studi Gender Vol. 8, No. 1 (2016): p.1-34.

Risdianto, D. "Perlindungan Terhadap Kelompok Minoritas di Indonesia dalam Mewujudkan Keadilan dan Persamaan di Hadapan Hukum.” Jurnal Rechts Vinding: Media Pembinaan Hukum Nasional, Vol. 6, No. 1 (2017): p. 125-142.

Samargandi, N., Al Mamun, M., Sohag, K., \& Alandejani, M. "Women at work in Saudi Arabia: Impact of ICT diffusion and financial development.” Technology in Society, Vol. 59, 101187. (2019).

Shuaib, F. S. "Administration of Islamic Law and Human Rights: The Basis and Its Trajectory in Malaysia." Al-Jami'ah: Journal of Islamic Studies, Vol. 56, No. 2 (2019): p. 281-304. 
Ijtihad: Jurnal Wacana Hukum Islam dan Kemanusiaan, Volume 20, No. 2, Desember 2020: 253-268

Soker, A.Mausu'ah Usroh (Insklopedi), denganjudul "Al-Usrotu Tahtari'atil Islam, Hukukuzaujiyah",. t.p. t.t.

Ss., S. S. Regional-global Governance Network on Women's Rights: CEDAW and its Implementation in ASEAN Countries. Procedia - Social and Behavioral Sciences, Vol. 172, (2015): p. 519-524.

Subhan, Z. Tafsir Kebencian, Studi Bias Gender dalam Tafsir Islam. Yogyakarta: LKiS, 1999.

Wibowo, D. E. "Peran Ganda Perempuan dan Kesetaraan Gender" Muwazah: Jurnal Kajian Gender. Muwazah: Vol. 3, No. 1 (2011): p. 356-364.

Zahara, R. A. "Potret Relasi Suami-Istri Masyarakat Petani dalam Mewujudkan Fungsi Keluarga.” Jurnal Pemikiran Keislaman, Vol. 28, No. 1 (2017): p. 123-146. 